\title{
Glass Waste Forms for Oak Ridge Tank Wastes: Fiscal Year 1998 Report for Task Plan SR-16WT-31, Task B
}

by

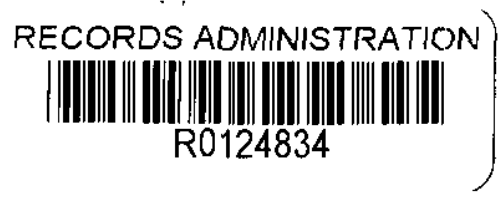

M. K. Andrews

Westinghouse Savannah River Company

Savannah River Site

Aiken, South Carolina 29808

J. R. Harbour

T. B. Edwards

P. J. Workman

This paper was prepared in connection with work done under the above contract number with the U. S.

Department of Energy. By acceptance of this paper, the publisher and/or recipient acknowledges the U. S. Government's right to retain a nonexclusive, royalty-free license in and to any copyright covering this paper, along with the right to reproduce and to authorize others to reproduce all or part of the copyrighted paper. 


\section{DISCLAIMER}

This report was prepared as an account of work sponsored by an agency of the United States Government. Neither the United States Government nor any agency thereof, nor any of their employees, makes any warranty, express or implied, or assumes any legal liability or responsibility for the accuracy, completeness, or usefulness of any information, apparatus, product, or process disclosed, or represents that its use would not infringe privately owned rights. Reference herein to any specific commercial product, process, or service by trade name, trademark, manufacturer, or otherwise does not necessarily constitute or imply its endorsement, recommendation, or favoring by the United States Government or any agency thereof. The views and opinions of authors expressed herein do.not necessarily state or reflect those of the United States Government or any agency thereof.

This report has been reproduced directly from the best available copy.

Available to DOE and DOE contractors from the Office of Scientific and Technical Information, P. O. Box 62, Oak Ridge, TN 37831; prices available from (423) 576-8401.

Available to the public from the National Technical Information Service, U. S. Department of Commerce, 5285. Port Royal Road, Springfield, VA 22161. 
WSRC-TR-98-00351

\title{
GLASS WASTE FORMS FOR OAK RIDGE TANK WASTES: FISCAL YEAR 1998 FINAL REPORT FOR TASK PLAN SR-16WT-31, TASK B
}

\author{
M. K. Andrews, J. R. Harbour, T. B. Edwards and P. J. Workman
}

Westinghouse Savannah River Company

Savannah River Technology Center

Aiken, SC 29808

This report was prepared in connection with work done under Contract No. DE-AC0989SR18035 with the U.S. Department of Energy. By acceptance of this report, the publisher and/or recipient acknowledges the U.S. Government's right to retain a nonexclusive, royaltyfree license in and to any copyright covering this report, along with the right to reproduce and to authorize others to reproduce all or part of the copyrighted report. 


\section{WESTINGHOUSE SAVANNAH RIVER COMPANY SAVANNAH RIVER TECHNOLOGY CENTER}

WSRC-TR-98-00351

September 28, 1998

\title{
GLASS WASTE FORMS FOR OAK RIDGE TANK WASTES: FISCAL YEAR 1998 REPORT FOR TASK PLAN SR-16WT-31, TASK B (U)
}

\author{
M. K. Andrews, J. R. Harbour, T. B. Edwards and P. J. Workman \\ Westinghouse Savannah River Company
}

\section{Introduction and Summary}

Through the Tanks Focus Area, the Office of Science and Technology has funded the Savannah River Technology Center (SRTC) and the Oak Ridge National Laboratory (ORNL) to develop formulations which can incorporate sludges from Oak Ridge (OR) Tank Farms into an immobilized waste form. SRTC has been developing a glass waste form, while ORNL has been developing a grout waste form, for the tank farms sludges. The four tank farms included in this task are:

\author{
Melton Valley Storage Tanks (MVST) \\ Bethel Valley Evaporator Service Tanks (BVEST) \\ Gunite and Associated Tanks (GAAT) \\ Old Hydrofracture Tanks (OHF)
}

The main focus of this project was on developing a glass formulation which would immobilize a sludge with a composition obtained from averaging the contents of all four tank farms (composite composition). Although blending the contents of all four tank farms is not feasible, this average composition provides a basis from which to develop a glass formulation. Once a frit formulation was developed which produced a durable glass waste form at relatively high waste loadings, then a statistically designed approach was implemented to determine the size of the sludge compositional window which could be adequately immobilized by the frit formulation.

After the compositional window was defined, the individual tank compositions were tested with the developed frit formulation. Components, such as thorium, which were minor in the composite composition, now were tested at higher levels for certain tank compositions. An investigation was also made into increasing the solubility of the "minor" components.

The results of these efforts demonstrate that waste loadings of $\sim 45 \mathrm{wt} \%$ sludge oxides can be achieved with the developed glass former composition. From an individual tank perspective, greater than $90 \%$ of the waste could be immobilized at $45 \mathrm{wt} \%$ loading. Those tanks having extreme chemical compositions could be vitrified by adjusting waste loading or modifying the glass former composition. However, Oak Ridge is now in the process of transferring all of the waste from the BVEST, GAAT, and OHF to the MVST tanks. The resultant blend will remove the extremes in composition such that essentially all of the waste can be immobilized at the $45 \%$ level. In fact, waste loadings higher than $45 \mathrm{wt} \%$ oxide are possible and have been 
demonstrated. A value of $45 \mathrm{wt} \%$ has been identified in this report to ensure that a conservative operating window for processing of the waste (liquidus and viscosity) is maintained.

The overall life cycle cost for the immobilization of the Oak Ridge sludge by vitrification is highly dependent on waste loading of the sludge in the glass. Therefore, it was an objective of this effort to achieve as high a waste loading as possible while still producing a processable, durable waste form. The high loading of $45 \mathrm{wt} \%$ oxide in glass, which corresponds to a volume reduction of $80 \%$, would lead to millions of dollars in savings. One of the major drivers of the cost is transportation and handling activities for disposal at WIPP. This cost is roughly 4 million dollars for the 200 canisters produced with a $45 \mathrm{wt} \%$ oxide loading. For comparison, immobilization at lower waste loadings (without a volume reduction) would lead to $\sim 1000$ canisters with a transportation and disposal cost of over 21 million dollars. The higher waste loadings also reduce other costs, such as operating and materials, associated with immobilization. A preliminary cost analysis is detailed in reference 1 . ORNL is documenting the life-cycle cost analysis.

Additional efforts at the SRTC included the verification of the glass formulation prior to the ORNL radioactive demonstration and technical consultations during the radioactive demonstration. SRTC performed durability tests on the simulated glasses. The normalized sodium and silicon leachate concentrations for the soda lime silica glasses readily met the Environmental Assessment glass (a borosilicate glass) benchmark limits for these two elements.

This report summarizes the SRTC results of Task B of Task Plan SR-16WT-31 for FY98.

\section{Objective}

Using ORNL information on the characterization of the tank waste sludges, SRTC performed extensive bench-scale vitrification studies using simulants. Several glass systems were tested to ensure the optimum glass composition (based on the glass liquidus temperature, viscosity and durability) is determined. This optimum composition will balance waste loading, melt temperature, waste form performance and disposal requirements. By optimizing the glass composition, a cost savings can be realized during vitrification of the waste. The preferred glass formulation was selected from the bench-scale studies and recommended to ORNL for further testing with samples of actual OR waste tank sludges.

\section{Experimental Details}

Studies were performed using simulant sludges that contained depleted uranium dioxide and reagent grade chemicals. The sludge simulant and appropriate glass-forming chemicals (or frit) were combined and placed in high-purity alumina crucibles. The samples were vitrified at $1300^{\circ} \mathrm{C}$ for four hours. The crucibles were then removed from the furnace and poured into stainless steel pans to provide an estimate of the viscosity of the glass. The relative viscosity of each sample was determined and given a numerical rating between 1 and 5 , with intervals of 0.5 . A viscosity rating of 2.5 to 3.5 was deemed acceptable. Lower or higher ratings were considered too viscous or too fluid. While a rating of 2.0 or 4.0 was marginal and could prove to be acceptable, depending on the melter system, it was decided to be conservative by considering it unacceptable. In addition to a viscosity rating, a liquidus rating was given to each sample based on visual observation for crystals or other non-glassy phases. The numerical rating ranged from 1 to 7 , with a minimum of 5 being considered acceptable. After the ratings were assigned, the glass was broken and ground for analysis. 
The glass samples were analyzed to determine the chemical composition. Each sample was dissolved by two separate dissolution methods according to approved procedures. The dissolutions were analyzed by Atomic Absorption (AA) spectrometry and Inductively Coupled Plasma Emission Spectroscopy (ICP-ES).

The glass durability was measured using the Product Consistency Test (PCT) ${ }^{2}$ The PCT is a crushed glass leach test that measures the releases of several elements from the glass. The test is performed in $90^{\circ} \mathrm{C}$ deionized water for seven days. The PCT creates leaching conditions that are more aggressive than those for the Toxicity Characteristic Leaching Procedure (TCLP) to provide information about glass durability under accelerated (worst case) leaching conditions. In addition, the PCT is a better indicator of the glass durability because it is a glass-dominated rather than a solution-dominated durability test. The results of the PCT test for each glass were compared to the Environmental Assessment (EA) glass ${ }^{3}$ to determine acceptability. The acceptance criteria for high-level waste glass states that the glass produced must be more durable than the EA glass. Since there is currently no durability criteria for low-level waste, the EA glass benchmark values will be used.

\section{FY97 Summary}

A report was written that details the results of the experiments performed in FY97. ${ }^{4}$ Initially, the sludge composition was held constant to determine the optimum frit composition required to produce a durable glass. The sludge composition used as the basis for the overall blended average of the four tank farms is presented in Table 1, along with the average composition of each of the four tank farms. These compositions are based on data provided by ORNL. ${ }^{5,6}$ Details on how this composition was calculated can be found in the FY97 report for this task.

Table 1. Composition of major components in each of the four OR Tank Farms, along with the statistically weighted average, Composite (in wt\%)

\begin{tabular}{|c||c|c|c|c|c|}
\hline Species & MVST & BVEST & GAAT & OHF & Composite \\
\hline $\mathrm{Al}$ & 1.4 & 0.6 & 9.3 & 7.1 & 2.5 \\
\hline $\mathrm{Ca}$ & 11.9 & 18.5 & 7.2 & 14.4 & 12.2 \\
\hline $\mathrm{Fe}$ & 0.5 & 0.8 & 5.4 & 2.6 & 1.3 \\
\hline $\mathrm{K}$ & 3.1 & 4.0 & 2.4 & 1.6 & 3.1 \\
\hline $\mathrm{Mg}$ & 2.2 & 3.7 & 1.7 & 1.4 & 2.3 \\
\hline $\mathrm{Na}$ & 16.8 & 16.0 & 19.0 & 4.8 & 16.2 \\
\hline $\mathrm{P}$ & 0.5 & 3.1 & 0.6 & 3.5 & 1.5 \\
\hline $\mathrm{Pb}$ & 0.1 & 0.2 & 0.7 & 0.2 & 0.2 \\
\hline $\mathrm{Si}$ & 1.6 & 0.5 & 1.9 & 6.8 & 1.7 \\
\hline $\mathrm{Th}$ & 1.5 & 4.4 & 5.6 & 47.1 & 3.7 \\
\hline $\mathrm{U}$ & 2.5 & 9.0 & 30.9 & 5.0 & 9.6 \\
\hline Chloride & 0.7 & 0.7 & 0.3 & 0.3 & 0.6 \\
\hline Fluoride & 0.0 & 0.0 & 1.3 & 0.1 & 0.2 \\
\hline Nitrate & 55.3 & 34.4 & 8.1 & 2.7 & 41.6 \\
\hline Nitrite & 0.8 & 1.1 & 0.0 & 1.1 & 1.1 \\
\hline Sulfate & 0.4 & 1.3 & 3.1 & 0.7 & 0.9 \\
\hline
\end{tabular}


As described in the FY97 report, a glass formulation was developed in the soda-lime-silica (SLS) glass system that could incorporate high waste loadings of the composite sludge. Three components $\left(\mathrm{SiO}_{2}, \mathrm{Fe}_{2} \mathrm{O}_{3}\right.$, and $\left.\mathrm{CaO}\right)$ were the most beneficial to the successful incorporation of the Oak Ridge sludges. Therefore, only these three components were used as the glass-formers for the additional studies.

The next studies (Phases I and III) involved statistically varying the sludge composition to determine how robust the three frit components were to changes in the sludge. In Phase I, the frit composition was also varied, while in Phase II, the frit composition was fixed. For both phases, the waste loading was $40 \pm 2 \mathrm{wt} \%$ sludge oxides. Phase I examined a relatively narrow range of sludge composition, while Phase II extended the sludge composition ranges to include a greater percentage of the overall tank wastes. The extended range, which was also used for FY98 testing, is provided in Table 2. This range included most of the variations within the BVEST and MVST tanks, as well as most of the averages for the GAAT and OHF tanks.

Table 2 - Extended Range of Sludge Components (as Oxides) for the OR Sludge (weight fraction)

\begin{tabular}{|c|c|c|}
\hline Oxide & Low & High \\
\hline \hline $\mathrm{Al}_{2} \mathrm{O}_{3}$ & 0.003 & 0.155 \\
\hline $\mathrm{CaO}$ & 0.140 & 0.410 \\
\hline $\mathrm{Fe}_{2} \mathrm{O}_{3}$ & 0.002 & 0.025 \\
\hline $\mathrm{K}_{2} \mathrm{O}$ & 0.015 & 0.136 \\
\hline $\mathrm{MgO}$ & 0.015 & 0.110 \\
\hline $\mathrm{Na}_{2} \mathrm{O}$ & 0.125 & 0.500 \\
\hline $\mathrm{SiO}_{2}$ & 0.005 & 0.106 \\
\hline $\mathrm{U}_{3} \mathrm{O}_{8}$ & 0.020 & 0.320 \\
\hline $\mathrm{Others}$ & 0.008 & 0.218 \\
\hline
\end{tabular}

Eight oxides were considered during these studies. All additional sludge components, considered initially to be minor components, were included in the "Others" category. While the minor components were included and varied in all of the experiments, the relative amounts of the minor components were held constant. The composition of "Others" is given in Table 3.

Table 3 - Composition of Others (Phase II through Phase IV)

\begin{tabular}{|c|c|}
\hline Compound & \% of Others \\
\hline \hline $\mathrm{Cl}$ & 5.57 \\
\hline $\mathrm{Cr}_{2} \mathrm{O}_{3}$ & 1.08 \\
\hline $\mathrm{F}$ & 1.86 \\
\hline $\mathrm{MnO}$ & 0.95 \\
\hline $\mathrm{PO}_{4}$ & 40.7 \\
\hline
\end{tabular}

\begin{tabular}{|c|c|}
\hline Compound & \% of Others \\
\hline \hline $\mathrm{PbO}$ & 1.82 \\
\hline $\mathrm{SO}_{4}$ & 8.50 \\
\hline $\mathrm{SrO}_{\mathrm{ThO}}$ & 0.63 \\
\hline $\mathrm{ZnO}$ & 37.5 \\
\hline & 1.43 \\
\hline
\end{tabular}

The high and low values for each of the oxides (including "Others") were used to calculate the extreme vertices of the final glass compositional region. Using statistical routines (as described 
in Appendix I of this document), a subset of the extreme vertices glass compositions was selected for testing. Generally, the centroid (the center of mass, or average, of the set of all extreme vertices) was also tested. Details on the statistical approach used for the FY97 experiments are provided in Appendix I of reference 4. An overview of this statistical approach which was also used in the FY98 experiments is provided in Appendix I of this report.

\section{Phase III Testing}

The Phase II results were plotted on a ternary diagram, with $\mathrm{SiO}_{2}$ on one axis, $\mathrm{Fe}_{2} \mathrm{O}_{3}$ and $\mathrm{CaO}$ on the second axis and all other components on the third axis. On this ternary diagram a region of the compositional space was beginning to form where acceptable liquidus and viscosity ratings were expected. This region indicated that additional $\mathrm{Fe}_{2} \mathrm{O}_{3}$ and $\mathrm{CaO}$ were desired. Therefore, for Phase $\mathrm{III}$ of this study, the frit was adjusted to a fixed composition containing higher $\mathrm{Fe}_{2} \mathrm{O}_{3}$ and $\mathrm{CaO}$ and lower $\mathrm{SiO}_{2}$ concentrations, and the waste loading was increased to $45 \pm 2 \mathrm{wt} \%$ sludge oxides. This would force the glass compositions into the acceptable regions.

A total of twelve glasses were selected for the Phase III study. These glasses were batched from reagent-grade chemicals and vitrified in a $1300^{\circ} \mathrm{C}$ furnace. After four hours, the glasses were removed from the furnace and poured into stainless steel pans. The viscosity of the glass was assessed during pouring and was assigned a numerical rating between 1 and 5 . A rating of 2.5 to 3.5 was considered acceptable. Lower or higher ratings were considered too viscous or too fluid. In addition to the viscosity rating, a liquidus rating was also given to the glass samples. This rating, which ranged from 1 to 7 , was based on the visual observation of crystals or discolorations. A liquidus rating of 5 or above was considered acceptable. The ratings assigned to the Phase III glasses are presented in Table 4.

Table 4 - Ratings for the Glasses in the Phase III Study

\begin{tabular}{|c|c|c|c|}
\hline ID & $\begin{array}{c}\text { Liquidus } \\
\text { rating }\end{array}$ & $\begin{array}{c}\text { Viscosity } \\
\text { rating }\end{array}$ & Acceptable? \\
\hline 1 & 7 & 3 & YES \\
\hline 2 & 7 & 3 & YES \\
\hline 3 & 7 & 3 & YES \\
\hline 4 & 2 & 3 & no \\
\hline 5 & 7 & 3 & YES \\
\hline 6 & 7 & 3 & YES \\
\hline 7 & 7 & 3 & YES \\
\hline 8 & 7 & 3 & YES \\
\hline 9 & 6 & 3 & YES \\
\hline 10 & 7 & 3 & YES \\
\hline 11 & 3 & 3 & no \\
\hline 12 & 7 & 3 & YES \\
\hline
\end{tabular}

All of the tested glasses were acceptable for viscosity, but two of the samples were unacceptable for liquidus. Even though two of the glasses were considered unacceptable, all twelve glasses were subjected to the PCT durability test to determine if the crystals present in the unacceptable glasses had an effect on the glass durability. The calcium, silicon and sodium PCT results for 
these glasses are shown in Table 5, along with the accepted values for the EA glass. The tested samples are soda-lime-silica glasses while EA is a borosilicate glass. Therefore, direct comparisons of some elements (such as calcium) can not be made.

Table 5 - PCT Results (in $\mathrm{g} / \mathrm{L}$ ) for Phase III

\begin{tabular}{|c|c|c|c|}
\hline ID & Ca & Si & Na \\
\hline 1 & 0.10 & 0.09 & 1.51 \\
\hline 2 & 0.04 & 0.21 & 2.33 \\
\hline 3 & 0.08 & 0.09 & 0.45 \\
\hline 4 & 0.02 & 0.59 & 26.5 \\
\hline 5 & 0.13 & 0.10 & 0.43 \\
\hline 6 & 0.10 & 0.09 & 0.53 \\
\hline 7 & 0.09 & 0.08 & 0.49 \\
\hline 8 & 0.12 & 0.08 & 0.25 \\
\hline 9 & 0.05 & 0.12 & 0.96 \\
\hline 10 & 0.08 & 0.08 & 0.26 \\
\hline 11 & 0.04 & 0.22 & 3.07 \\
\hline 12 & 0.09 & 0.08 & 0.60 \\
\hline & & & \\
\hline EA $^{7}$ & NA & 3.9 & 13.3 \\
\hline
\end{tabular}

NOTE: The Ca release was not calculated for the EA glass because it is a borosilicate glass

The PCT results for sodium indicate that the two glasses considered unacceptable (\# 4 and 11) had the highest releases for sodium. Calcium and silicon results did not vary as much as the sodium results. Since the glasses with unacceptable ratings had the highest sodium release, it was decided not to perform the PCT on glasses considered unacceptable.

The results of the first three phases were plotted on a ternary diagram with $\mathrm{SiO}_{2}$ on one side, $\mathrm{Fe}_{2} \mathrm{O}_{3} \& \mathrm{CaO}$ on another side and all other components on the third side. This ternary is provided in Figure 1. The "+" symbols indicate a glass with an acceptable liquidus and viscosity and the " $z$ " symbols indicate a glass with an unacceptable rating for liquidus, viscosity or both. A region that is greater than $\sim 0.33 \mathrm{SiO}_{2}$ and $\sim 0.29\left(\mathrm{Fe}_{2} \mathrm{O}_{3} \& \mathrm{CaO}\right)$ appears to have only acceptable glasses. Lithium is included on this ternary because it was used as an additive during FY97. It was not included in any of the FY98 testing. 


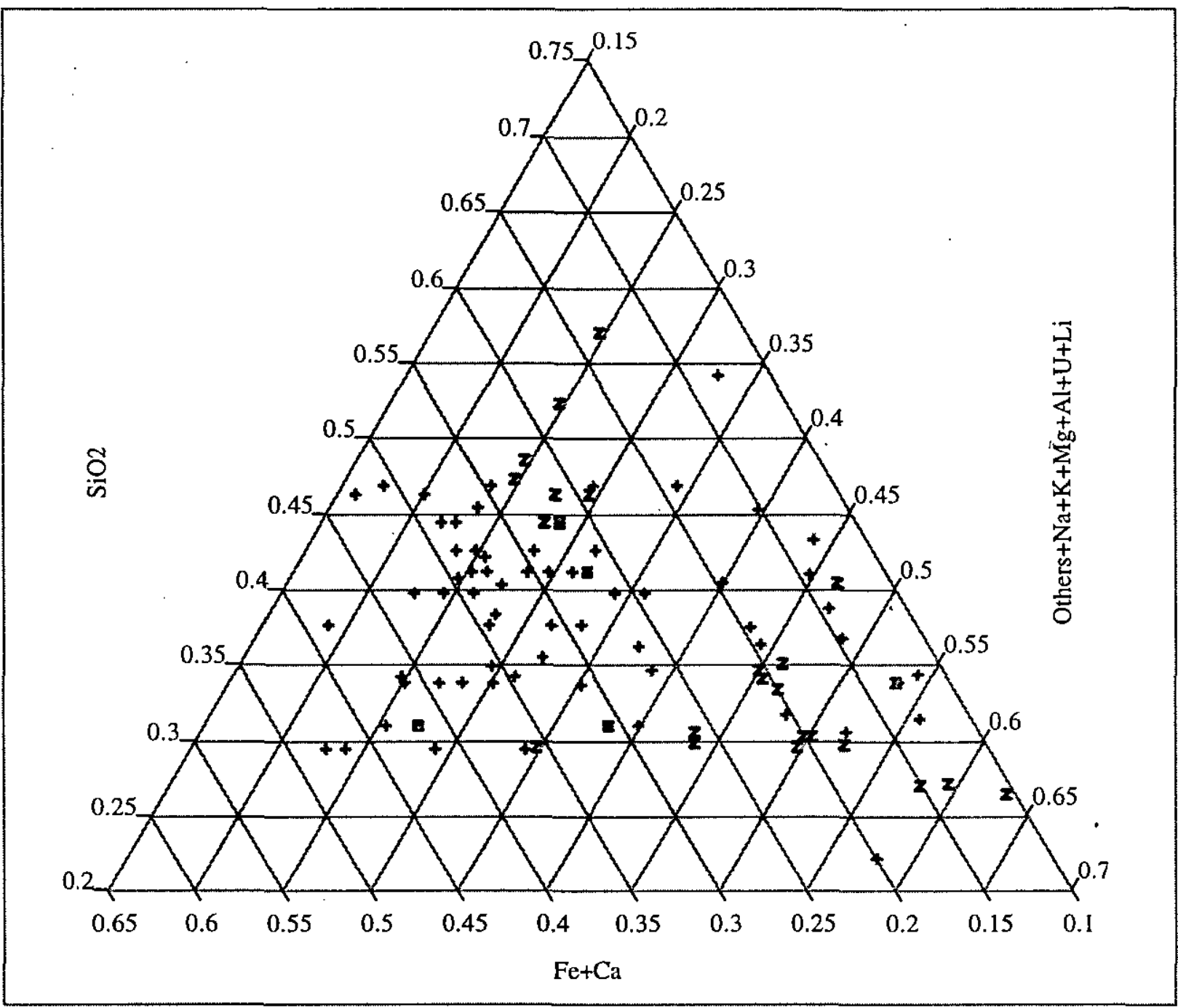

Figure 1 - Ternary Diagram of Glass Samples through Phase III Testing ( $\mathrm{z}=$ unacceptable glass; $+=$ acceptable glass)

\section{Phase IV Testing}

As each phase of testing was completed, the results were incorporated into statistical models that were developed from the subjective viscosity and liquidus data. These models were used to identify influential sludge components, to determine the boundaries of the composition region with acceptable liquidus and viscosity properties, and predict the behavior of these properties for the glasses selected for additional testing. For the next set of tests (Phase IV), the glasses were chosen to further define these prediction models and the regions of property acceptability. Eighteen glasses were selected. The first nine glasses were designed to test the viscosity model. The next three samples were designed to test the liquidus model, and the remaining six samples were predicted to be on the borderline of acceptability for both liquidus and viscosity. The viscosity and liquidus ratings of the eighteen tested glass samples are shown in Table 6. 
Table 6 - Ratings for the Glasses in the Phase IV Study

\begin{tabular}{|c|c|c|c|}
\hline ID & $\begin{array}{c}\text { Liquidus } \\
\text { rating }\end{array}$ & $\begin{array}{c}\text { Viscosity } \\
\text { rating }\end{array}$ & Acceptable? \\
\hline 1 & 7 & 2.5 & YES \\
\hline 2 & 7 & 2.5 & YES \\
\hline 3 & 6 & 2.5 & YES \\
\hline 4 & 7 & 2.5 & YES \\
\hline 5 & 6 & 3 & YES \\
\hline 6 & 7 & 2.5 & YES \\
\hline 7 & 7 & 3 & YES \\
\hline 8 & 7 & 3 & YES \\
\hline 9 & 7 & 3 & YES \\
\hline 10 & 3 & 2 & no \\
\hline 11 & 3 & 2 & no \\
\hline 12 & 3 & 1 & no \\
\hline 13 & 4 & 3 & no \\
\hline 14 & 7 & 3 & YES \\
\hline 15 & 4 & 3 & no \\
\hline 16 & 7 & 3 & YES \\
\hline 17 & 7 & 3 & YES \\
\hline 18 & 7 & 3 & YES \\
\hline & & & \\
\hline
\end{tabular}

The liquidus model predicted the results reasonably well and the viscosity model was able to predict trends; i.e., the viscosity model adequately indicated which changes in glass composition would lead to improved viscosity ratings and which would worsen the rating. The results of this testing were incorporated into the models to improve the predictions. It should be noted that while the models are objective, the liquidus and viscosity ratings are purely subjective, based on experience and comparison to standards. To avoid potential bias, the predicted values were not made known to those assigning the ratings.

The acceptable glasses, as listed in Table 6, were subjected to the PCT. Table 7 presents the results for the thirteen acceptable glasses. All of the results are below $1 \mathrm{~g} / \mathrm{L}$ for all three elements, indicating that these glasses are very durable.

Over $90 \%$ of the ORNL waste tanks are covered by the acceptable glass region. Some of the compositions that are not included in the acceptable region contain higher amounts of the "minor" components, such as thorium. Therefore, the next phase of the testing further investigated some of the "minor" components. 
Table 7 - PCT Results (in g/L) for Phase IV Acceptable Glasses

\begin{tabular}{|c|c|c|c|}
\hline ID & $\mathbf{C a}$ & $\mathbf{S i}$ & $\mathbf{N a}$ \\
\hline \hline 1 & 0.03 & 0.10 & 0.49 \\
\hline 2 & 0.04 & 0.10 & 0.69 \\
\hline 3 & 0.02 & 0.07 & 0.36 \\
\hline 4 & 0.06 & 0.07 & 0.41 \\
\hline 5 & 0.03 & 0.11 & 0.56 \\
\hline 6 & 0.03 & 0.11 & 0.46 \\
\hline 7 & 0.04 & 0.09 & 0.60 \\
\hline 8 & 0.03 & 0.12 & 0.94 \\
\hline 9 & 0.01 & 0.10 & 0.47 \\
\hline 14 & 0.03 & 0.13 & 0.67 \\
\hline 16 & 0.06 & 0.12 & 0.58 \\
\hline 17 & 0.04 & 0.13 & 0.65 \\
\hline 18 & 0.03 & 0.17 & 0.75 \\
\hline
\end{tabular}

\section{Phase V Testing}

The composition of the "Others" components listed in Table 3 includes components that are known to affect liquidus or viscosity. Plus, by including all of the "minor" components together, the models can not determine the effect of the individual components. Therefore, Phase $\mathrm{V}$ examined the effects of four of the minor components: $\mathrm{Cr}_{2} \mathrm{O}_{3}, \mathrm{PO}_{4}, \mathrm{SO}_{4}$, and $\mathrm{ThO}_{2}$. These four components were selected either because they are known to have limited solubility in glass or because they are a major component of some of the tank compositions. The ranges of these four components, which were expanded for Phase $\mathrm{V}$, are provided in Table 8 . The ranges for the other sludge components remained the same as shown in Table 2.

Table 8 - Initial Range for "Minor" Components during Phase V (in wt\%)

\begin{tabular}{|c|c|c|}
\hline Component & Low Value & High Value \\
\hline \hline $\mathrm{Cr}_{2} \mathrm{O}_{3}$ & 0.05 & 0.2 \\
\hline $\mathrm{PO}_{4}$ & 2.0 & 5.0 \\
\hline $\mathrm{SO}_{4}$ & 0.5 & 1.5 \\
\hline $\mathrm{ThO}_{2}$ & 2.5 & 4.5 \\
\hline Others-2 & 0.03 & 3.0 \\
\hline
\end{tabular}

Because the composition of "Others" no longer included $\mathrm{Cr}_{2} \mathrm{O}_{3}, \mathrm{PO}_{4}, \mathrm{SO}_{4}$, and $\mathrm{ThO}_{2}$, a new component, "Others-2" was used. Table 9 presents the composition of "Others-2". Compared to the original "Others", the investigated range of "Others-2" was narrowed, since it contained only six components. 
Table 9 - Composition of "Others-2"

(in wt\%)

\begin{tabular}{|c|c|}
\hline Component & \% of Others-2 \\
\hline \hline $\mathrm{Cl}$ & 45.4 \\
\hline $\mathrm{Fl}$ & 15.2 \\
\hline $\mathrm{MnO}$ & 7.7 \\
\hline $\mathrm{PbO}$ & 14.9 \\
\hline $\mathrm{SrO}$ & 5.1 \\
\hline $\mathrm{ZnO}$ & 11.7 \\
\hline
\end{tabular}

Twenty-three glasses were selected from the extreme vertices of the new compositional region. These samples were chosen to provide information regarding possible linear effects among the components, including $\mathrm{Cr}_{2} \mathrm{O}_{3}, \mathrm{PO}_{4}, \mathrm{SO}_{4}$, and $\mathrm{ThO}_{2}$. The liquidus and viscosity ratings for the tested glasses are given in Table 10.

Table 10 - Ratings for the Glasses in the Phase V Study

\begin{tabular}{|c|c|c|c|}
\hline ID & $\begin{array}{c}\text { Liquidus } \\
\text { rating }\end{array}$ & $\begin{array}{l}\text { Viscosity } \\
\text { rating }\end{array}$ & Acceptable? \\
\hline 1 & 7 & 2.5 & YES \\
\hline 2 & 6 & 2.5 & YES \\
\hline 3 & 6 & 2 & no \\
\hline 4 & 6 & 2.5 & YES \\
\hline 5 & 1 & 1 & no \\
\hline 6 & 6 & 2.5 & YES \\
\hline 7 & 4 & 2.5 & no \\
\hline 8 & 3 & 2 & no \\
\hline 9 & 7 & 2.5 & YES \\
\hline 10 & 5 & 2 & no \\
\hline 11 & 7 & 2.5 & YES \\
\hline 12 & 7 & 2.5 & YES \\
\hline 13 & 1 & 2.5 & no \\
\hline 14 & 5 & 2 & no \\
\hline 15 & 7 & 2.5 & YES \\
\hline 16 & 7 & 2.5 & YES \\
\hline 17 & 4 & 2 & no \\
\hline 18 & 2 & 2.5 & no \\
\hline 19 & 5 & 2 & no \\
\hline 20 & 7 & 3 & YES \\
\hline 21 & 7 & 2.5 & YES \\
\hline 22 & 7 & 3 & YES \\
\hline 23 & 7 & 3 & YES \\
\hline
\end{tabular}


Thirteen of the tested glasses were considered acceptable, while ten were deemed unacceptable. The durability of the acceptable glasses was determined using the PCT. The PCT results for the Phase V glasses are provided in Table 11. The glasses are very durable in terms of calcium and silicon, but are less durable for sodium.

Table 11 - PCT Results (in g/L) for Phase V Acceptable Glasses

\begin{tabular}{|c|c|c|c|}
\hline ID & Ca & Si & Na \\
\hline 1 & 0.00 & 0.49 & 4.97 \\
\hline 2 & 0.00 & 0.84 & 5.65 \\
\hline 4 & 0.01 & 0.40 & 4.01 \\
\hline 6 & 0.01 & 0.63 & 7.94 \\
\hline 9 & 0.00 & 0.53 & 4.75 \\
\hline 11 & 0.01 & 0.35 & 2.85 \\
\hline 12 & 0.01 & 0.32 & 3.62 \\
\hline 15 & 0.01 & 0.40 & 4.94 \\
\hline 16 & 0.01 & 0.34 & 4.01 \\
\hline 20 & 0.02 & 0.21 & 2.72 \\
\hline 21 & 0.05 & 0.13 & 1.07 \\
\hline 22 & 0.01 & 0.31 & 4.08 \\
\hline 23 & 0.08 & 0.07 & 0.37 \\
\hline
\end{tabular}

\section{Phase VI Testing}

At this point, it was decided to test the developed formulation with simulants of each of the individual tank compositions. Appendix II provides the compositions investigated. The glass compositions were calculated and plotted on the ternary diagram, shown as black squares in Figure 2. (Glasses containing lithium have now been excluded from the diagram). The majority of the glass compositions of the individual tanks fell within the region where acceptable glasses were expected. A few were in regions that did not have enough information to predict the acceptability of the glasses. 


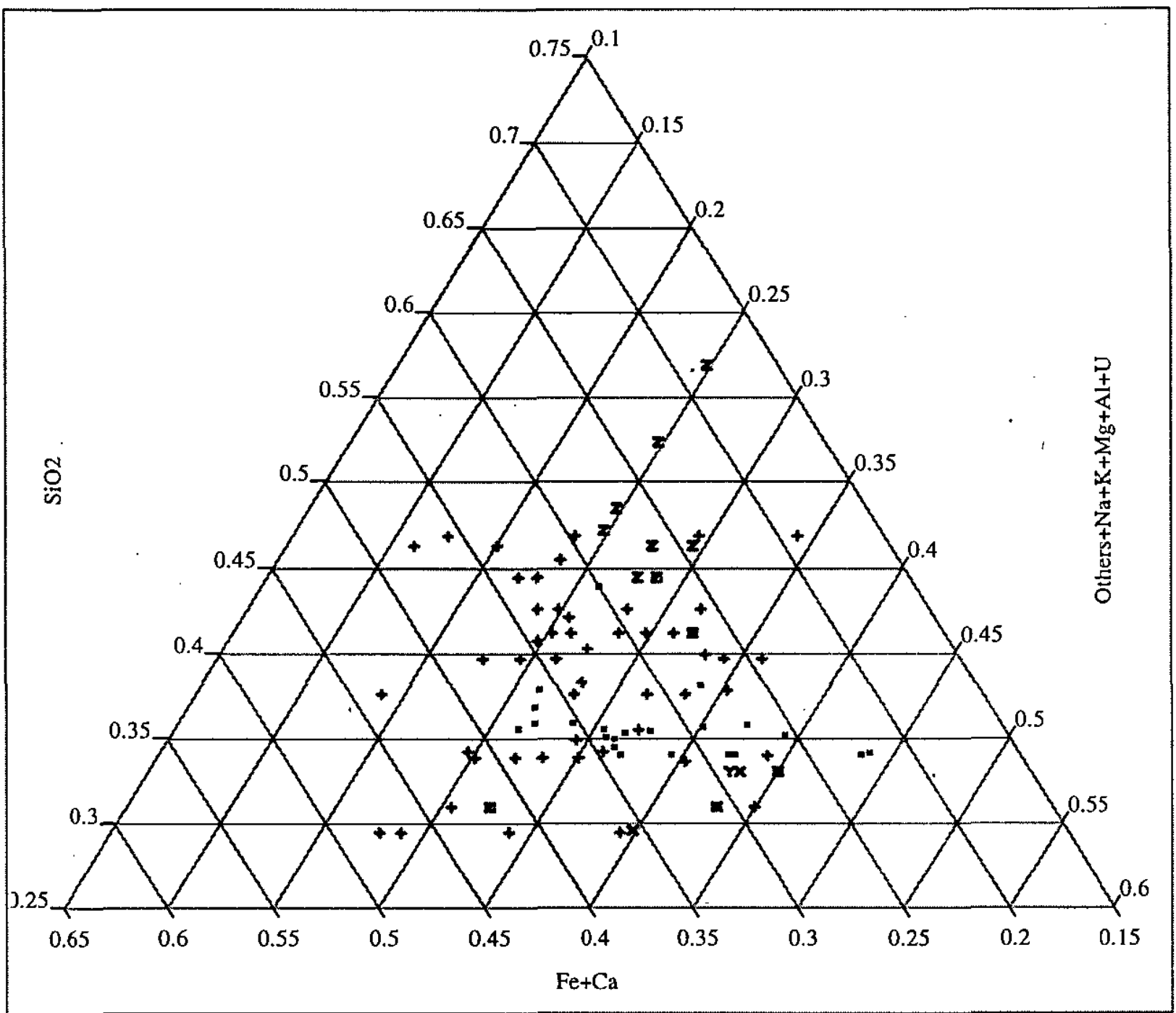

Figure 2 - Ternary Diagram with the Individual Tank Compositions (Represented by Squares)

Simulants of the 20 tank compositions were batched and combined with the developed glass frit. A waste loading of $45 \mathrm{wt} \%$ sludge oxides was used in the initial tests. The samples were melted at $1300^{\circ} \mathrm{C}$ for four hours and then the glass was poured into stainless steel pans. Viscosity and liquidus ratings were assigned to each of the glasses. Table 12 shows the ratings for the individual tank compositions. 
Table 12 - Ratings for the Individual Tank Compositions at $45 \mathrm{wt} \%$ Sludge Oxide Loading (Phase VI)

\begin{tabular}{|c|c|c|c|}
\hline ID & $\begin{array}{c}\text { Liquidus } \\
\text { rating }\end{array}$ & $\begin{array}{c}\text { Viscosity } \\
\text { rating }\end{array}$ & Acceptable? \\
\hline OHF-T1 & 3 & 1.5 & no \\
\hline OHF-T2 & 4 & 2.5 & no \\
\hline OHF-T3 & 6 & 3 & YES \\
\hline OHF-T4 & 1 & 1 & no \\
\hline OHF-T9 & 7 & 3 & YES \\
\hline GAAT-W5 & 6 & 2.5 & YES \\
\hline GAAT-W6 & 6 & 2.5 & YES \\
\hline GAAT-W7 & 5 & 2.5 & YES \\
\hline GAAT-W8 & 4 & 3 & no \\
\hline GAAT-W9 & 6 & 3 & YES \\
\hline GAAT-W10 & 4 & 2 & no \\
\hline BVEST-W21 & 6 & 3 & YES \\
\hline BVEST-W22 & 7 & 2.5 & YES \\
\hline BVEST-W23 & 3 & 3 & no \\
\hline MVST-W24 & 7 & 3 & YES \\
\hline MVST-W25 & 7 & 3 & YES \\
\hline MVST-W26 & 6 & 3 & YES \\
\hline MVST-W27 & 7 & 2.5 & YES \\
\hline MVST-W28 & 7 & 3 & YES \\
\hline MVST-W31 & 7 & 2.5 & YES \\
\hline
\end{tabular}

Most of the unacceptable glasses were from the OHF tanks. These tanks contain the least volume of waste, but are the most different in composition. A large portion of the OHF tanks consists of thorium. An examination of the other unacceptable glasses showed that these compositions also contained higher concentrations of thorium.

A comparison was made between the assigned and the predicted liquidus and viscosity ratings for each of the tank compositions. The comparison is shown in Table 13. Although the predicted ratings do not agree exactly with the assigned ratings, the trends in the predicted correlate well. For instance, the lowest prediction for liquidus $(-21.7)$ corresponds to the lowest liquidus rating (1). 
Table 13 - Predicted vs. Actual Ratings at 45 wt\% Sludge Oxide Loading (Phase VI)

\begin{tabular}{|c|c|c|c|c|}
\hline ID & $\begin{array}{c}\text { Liquidus } \\
\text { rating }\end{array}$ & $\begin{array}{c}\text { Predicted } \\
\text { Liquidus }\end{array}$ & $\begin{array}{c}\text { Viscosity } \\
\text { rating }\end{array}$ & $\begin{array}{c}\text { Predicted } \\
\text { Viscosity }\end{array}$ \\
\hline \hline OHF-T1 & 3 & -14.6 & 1.5 & 1.9 \\
\hline OHF-T2 & 4 & -13.7 & 2.5 & 2.3 \\
\hline OHF-T3 & 6 & -5.6 & 3 & 1.9 \\
\hline OHF-T4 & 1 & -21.7 & 1 & 1.7 \\
\hline OHF-T9 & 7 & -1.2 & 3 & 2.7 \\
\hline GAAT-W5 & 6 & 10.5 & 2.5 & 4.2 \\
\hline GAAT-W6 & 6 & 11.6 & 2.5 & 2.6 \\
\hline GAAT-W7 & 5 & 7.4 & 2.5 & 1.9 \\
\hline GAAT-W8 & 4 & -2.5 & 3 & 1.4 \\
\hline GAAT-W9 & 6 & 4.4 & 3 & 2.7 \\
\hline GAAT-W10 & 4 & 3.6 & 2 & 1.7 \\
\hline BVEST-W21 & 6 & 6.5 & 3 & 2.7 \\
\hline BVEST-W22 & 7 & 11.3 & 2.5 & 4.1 \\
\hline BVEST-W23 & 3 & 1.4 & 3 & 2.5 \\
\hline MVST-W24 & 7 & 5.9 & 3 & 2.8 \\
\hline MVST-W25 & 7 & 4.9 & 3 & 2.6 \\
\hline MVST-W26 & 6 & 5.7 & 3 & 2.8 \\
\hline MVST-W27 & 7 & 6.3 & 2.5 & 2.9 \\
\hline MVST-W28 & 7 & 6.0 & 3 & 2.8 \\
\hline MVST-W31 & 7 & 3.4 & 2.5 & 2.6 \\
\hline
\end{tabular}

The PCT results for the tank compositions that formed acceptable glasses are given in Table 14 . Nearly all of the results are less than $1 \mathrm{~g} / \mathrm{L}$ for each of the three elements $(\mathrm{Ca}, \mathrm{Si}$ and $\mathrm{Na})$. This indicates that the glasses produced are very durable.

Table 14 - PCT Results (in $\mathrm{g} / \mathrm{L}$ ) for Phase VI Acceptable Glasses at 45 wt\% sludge loading

\begin{tabular}{|c|c|c|c|}
\hline ID & Ca & Si & Na \\
\hline OHF-T3 & 0.04 & 0.10 & 0.69 \\
\hline OHF-T9 & 0.07 & 0.07 & 0.50 \\
\hline GAAT-W5 & 0.06 & 0.11 & 0.53 \\
\hline GAAT-W6 & 0.07 & 0.09 & 0.34 \\
\hline GAAT-W7 & 0.06 & 0.14 & 0.89 \\
\hline GAAT-W9 & 0.05 & 0.10 & 0.62 \\
\hline BVEST-W21 & 0.10 & 0.06 & 0.35 \\
\hline BVEST-W22 & 0.07 & 0.08 & 0.29 \\
\hline MVST-W24 & 0.08 & 0.08 & 0.62 \\
\hline MVST-W25 & 0.08 & 0.07 & 0.43 \\
\hline MVST-W26 & 0.10 & 0.10 & 0.73 \\
\hline MVST-W27 & 0.00 & 0.59 & 0.48 \\
\hline MVST-W28 & 0.08 & 0.13 & 1.17 \\
\hline MVST-W31 & 0.05 & 0.12 & 0.70 \\
\hline
\end{tabular}


All of the glasses that were acceptable at $45 \mathrm{wt} \%$ sludge oxide loading were tested at $50 \mathrm{wt} \%$ waste loading. The ratings for these fourteen glasses are given in Table 15.

Table 15 - Ratings for the 14 Individual Tank Compositions at $50 \mathrm{wt} \%$ Sludge Oxide Loading (Phase VI-B)

\begin{tabular}{|c|c|c|c|}
\hline ID & $\begin{array}{c}\text { Liquidus } \\
\text { rating }\end{array}$ & $\begin{array}{c}\text { Viscosity } \\
\text { rating }\end{array}$ & Acceptable? \\
\hline OHF-T3 & 4 & 2.5 & no \\
\hline OHF-T9 & 6 & 3 & YES \\
\hline GAAT-W5 & 4 & 1.5 & no \\
\hline GAAT-W6 & 4 & 2 & no \\
\hline GAAT-W7 & 5 & 3 & YES \\
\hline GAAT-W9 & 4 & 2 & no \\
\hline BVEST-W21 & 4 & 2 & no \\
\hline BVEST-W22 & 7 & 3 & YES \\
\hline MVST-W24 & 4 & 2 & no \\
\hline MVST-W25 & 5 & 2.5 & YES \\
\hline MVST-W26 & 5 & 2.5 & YES \\
\hline MVST-W27 & 4 & 2 & no \\
\hline MVST-W28 & 3 & 2 & no \\
\hline MVST-W31 & 4 & 3 & no \\
\hline
\end{tabular}

The tank compositions that produced unacceptable glasses at $45 \mathrm{wt} \%$ loadings were then tested at $35 \mathrm{wt} \%$ sludge oxide loadings. The six glasses were assigned liquidus and viscosity ratings as shown in Table 16. Although four of the glasses were still unacceptable, the ratings did improve at the lower waste loadings.

Table 16 - Ratings for the Six Individual Tank Compositions at $35 \mathrm{wt} \%$ Sludge Oxide Loading (Phase VI-C)

\begin{tabular}{|c|c|c|c|}
\hline ID & $\begin{array}{c}\text { Liquidus } \\
\text { rating }\end{array}$ & $\begin{array}{c}\text { Viscosity } \\
\text { rating }\end{array}$ & Acceptable? \\
\hline \hline OHF-T1 & 6 & 2 & no \\
\hline OHF-T2 & 5 & 2 & no \\
\hline OHF-T4 & 3 & 1.5 & no \\
\hline GAAT-W8 & 6 & 3 & YES \\
\hline GAAT-W10 & 5 & 2 & no \\
\hline BVEST-W23 & 7 & 2.5 & YES \\
\hline
\end{tabular}

The ternary diagram showing the results of this testing is provided in Figure 3. There are now unacceptable glasses in the region $>0.33 \mathrm{SiO}_{2}$ and $>0.29\left(\mathrm{Fe}_{2} \mathrm{O}_{3} \& \mathrm{CaO}\right)$. Further investigation into the unacceptable glasses showed that these compositions were from tanks that contained significant quantities of $\mathrm{ThO}_{2}$. During Phase $\mathrm{V}$, the maximum $\mathrm{ThO}_{2}$ concentration tested was 4.5 
wt $\%$ in the glass, while some of the glass from the individual tanks contained $>11 \mathrm{wt} \% \mathrm{ThO}_{2}$ in the glass.

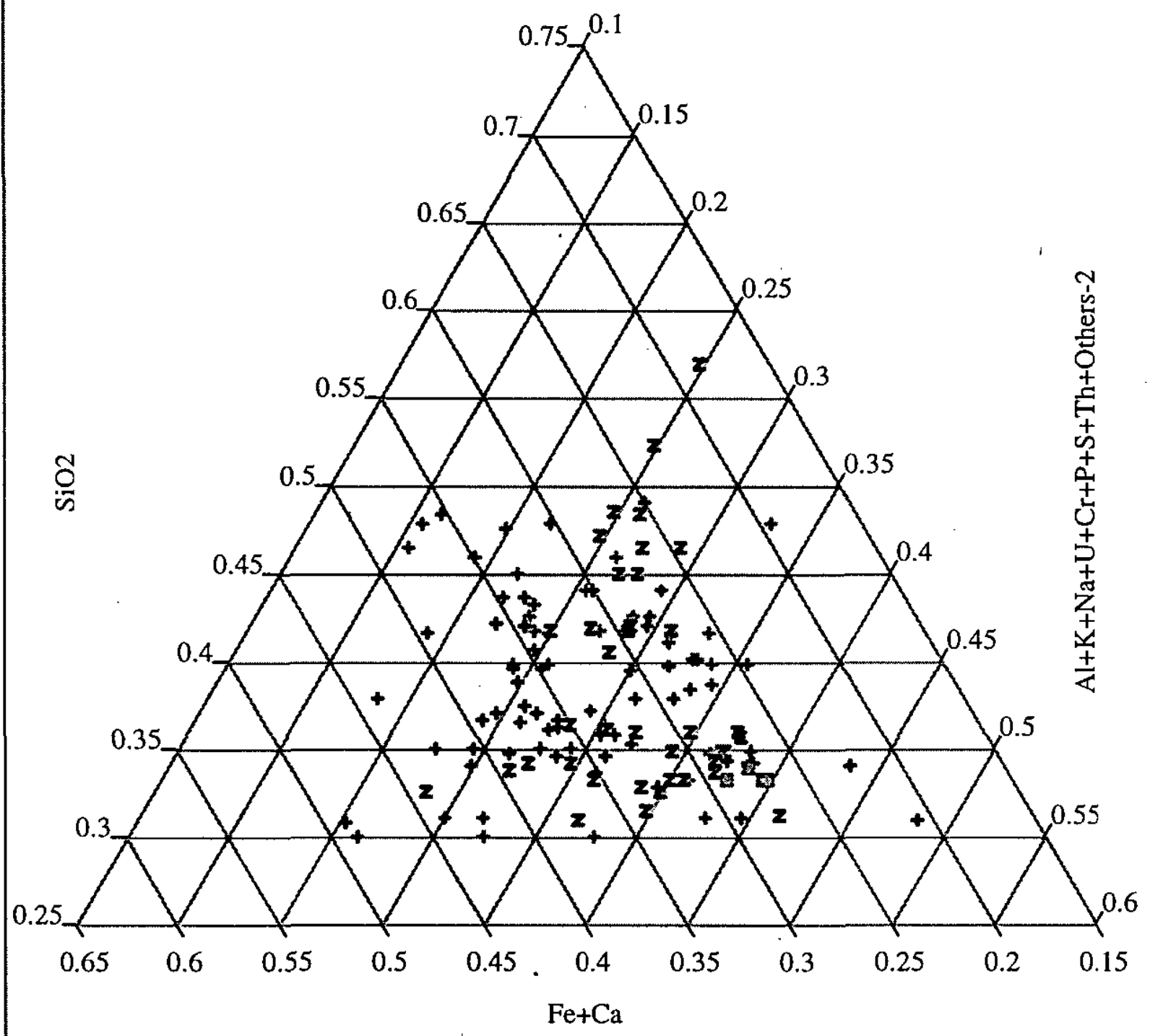

Figure 3 - Ternary Diagram with the Results of Phase VI Testing ( $\mathrm{z}=$ unacceptable glass; $+=$ acceptable glass;

BOLD symbol = individual tank composition)

\section{Phase VII Testing}

To further investigate the impact of thorium, the ranges of thorium, chromium, phosphate and sulfate were expanded for Phase VII, as shown in Table 17. The composition of "Others-2" is the same as listed in Table 9. The range of "Others-2" was not expanded for this testing because it did not seem to affect either the liquidus or viscosity rating. 
Table 17 - Extended Range for "Minor" Components during Phase VII (in wt\%)

\begin{tabular}{|c|c|c|}
\hline Component & Low Value & High Value \\
\hline \hline $\mathrm{Cr}_{2} \mathrm{O}_{3}$ & 0.05 & 0.5 \\
\hline $\mathrm{PO}_{4}$ & 2.0 & 10.0 \\
\hline $\mathrm{SO}_{4}$ & 0.5 & 2.5 \\
\hline $\mathrm{ThO}_{2}$ & 2.5 & 20.0 \\
\hline Others-2 & 0.03 & 3.0 \\
\hline
\end{tabular}

Twenty-one glasses were selected from the statistically'generated extreme vertices. The liquidus and viscosity ratings for these glasses are provided in Table 18.

Table 18 - Ratings for the Phase VII Study

\begin{tabular}{|c|c|c|c|}
\hline ID & $\begin{array}{c}\text { Liquidus } \\
\text { rating }\end{array}$ & $\begin{array}{c}\text { Viscosity } \\
\text { rating }\end{array}$ & Acceptable? \\
\hline 1 & 6 & 2.5 & YES \\
\hline 2 & 3 & 3 & no \\
\hline 3 & 4 & 3 & no \\
\hline 4 & 7 & 2.5 & YES \\
\hline 5 & 7 & 3 & YES \\
\hline 6 & 6 & 2.5 & YES \\
\hline 7 & 4 & 3 & no \\
\hline 8 & 1 & 2.5 & no \\
\hline 9 & 4 & 2.5 & no \\
\hline 10 & 7 & 3 & YES \\
\hline 11 & 7 & 3 & YES \\
\hline 12 & 3 & 1 & no \\
\hline 13 & 6 & 3 & YES \\
\hline 14 & 7 & 4 & no \\
\hline 15 & 6 & 2 & no \\
\hline 16 & 5 & 3 & YES \\
\hline 17 & 5 & 3 & YES \\
\hline 18 & 6 & 3.5 & YES \\
\hline 19 & 4 & 2.5 & no \\
\hline 20 & 7 & 2.5 & YES \\
\hline 21 & 7 & 2.5 & YES \\
\hline
\end{tabular}

The PCT results for the acceptable glasses are shown in Table 19. 
Table 19 - PCT Results (in g/L) for Phase VII Acceptable Glasses

\begin{tabular}{|c|c|c|c|}
\hline ID & Ca & Si & Na \\
\hline 1 & 0.00 & 0.98 & 22.44 \\
\hline 4 & 0.08 & 0.07 & 0.16 \\
\hline 5 & 0.12 & 0.09 & 0.25 \\
\hline 6 & 0.09 & 0.06 & 0.17 \\
\hline 10 & 0.01 & 0.14 & 1.00 \\
\hline 11 & 0.02 & 0.13 & 0.47 \\
\hline 13 & 0.09 & 0.08 & 0.20 \\
\hline 16 & 0.11 & 0.09 & 0.38 \\
\hline 17 & 0.01 & 0.16 & 0.77 \\
\hline 18 & 0.06 & 0.09 & 0.34 \\
\hline 20 & 0.16 & 0.06 & 0.47 \\
\hline 21 & 0.06 & 0.09 & 0.34 \\
\hline
\end{tabular}

The results for liquidus and viscosity were plotted against each oxide concentration in the glass. Figures 4 and 5 show the graphs for thorium oxide. These graphs provided insight into the concentration ranges investigated for each oxide, along with any potential solubility limits.

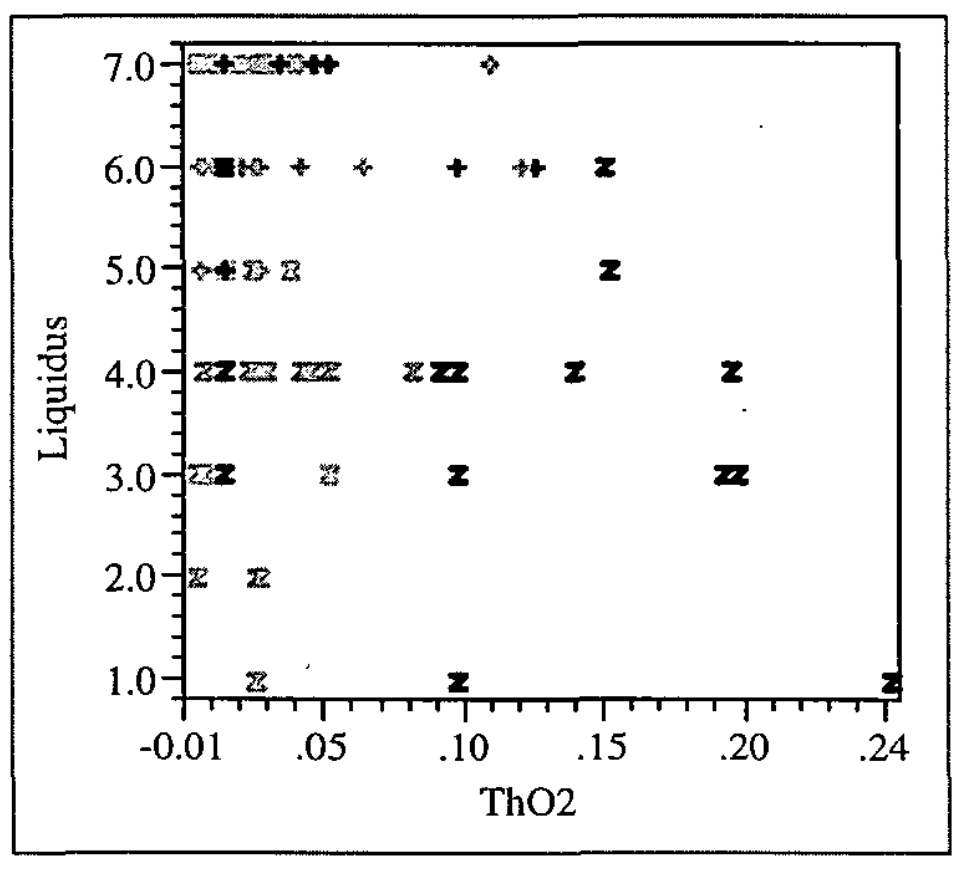

Figure 4 - Liquidus versus $\mathrm{ThO}_{2}$ through Phase VII

( $\mathrm{z}=$ unacceptable glass $;+=$ acceptable glass)

Analysis of the data shown in Figures 4 and 5, revealed that acceptable glasses with up to 12 wt $\% \mathrm{ThO}_{2}$ in the glass could be produced. However, some compositions with levels approaching $12 \mathrm{wt} \%$ did not produce acceptable glasses. Further research would be required to determine 
what interactions with thorium are occurring in the glass. No acceptable glasses were produced in these studies at $\mathrm{ThO}_{2}$ concentrations significantly above $12 \mathrm{wt} \%$, but higher levels could be possible with a different glass formulation.

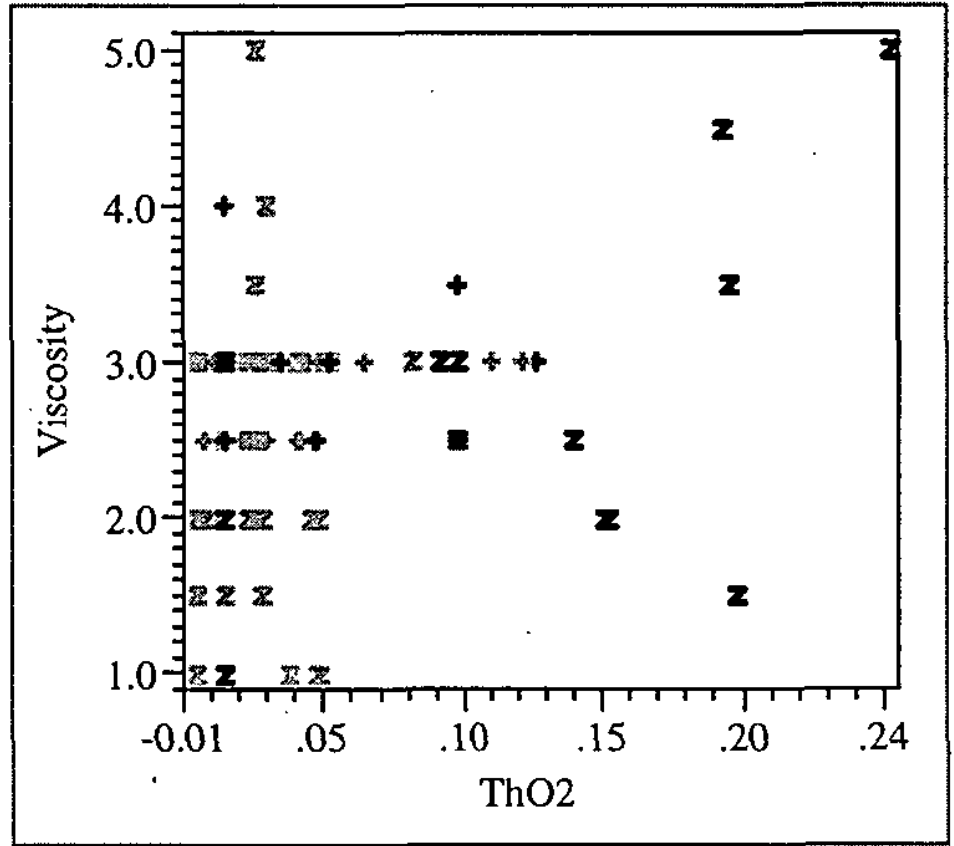

Figure $5-$ Viscosity versus $\mathrm{ThO}_{2}$ through Phase VII ( $\mathrm{z}=$ unacceptable glass; $+=$ acceptable glass)

The results through Phase VII were plotted on the ternary diagram shown in Figure 6. The bold symbols in Figure 6 are the glasses tested as part of Phase VII. While there are a few unacceptable glasses in the region of interest $\left(>0.33 \mathrm{SiO}_{2}\right.$ and $\left.>0.29\left(\mathrm{Fe}_{2} \mathrm{O}_{3} \& \mathrm{CaO}\right)\right)$, these glasses contain significant quantities of thorium oxide. Since ORNL plans to blend all of the sludges together, the overall concentration of thorium in the sludge will be reduced and therefore, should not be a major concern. 


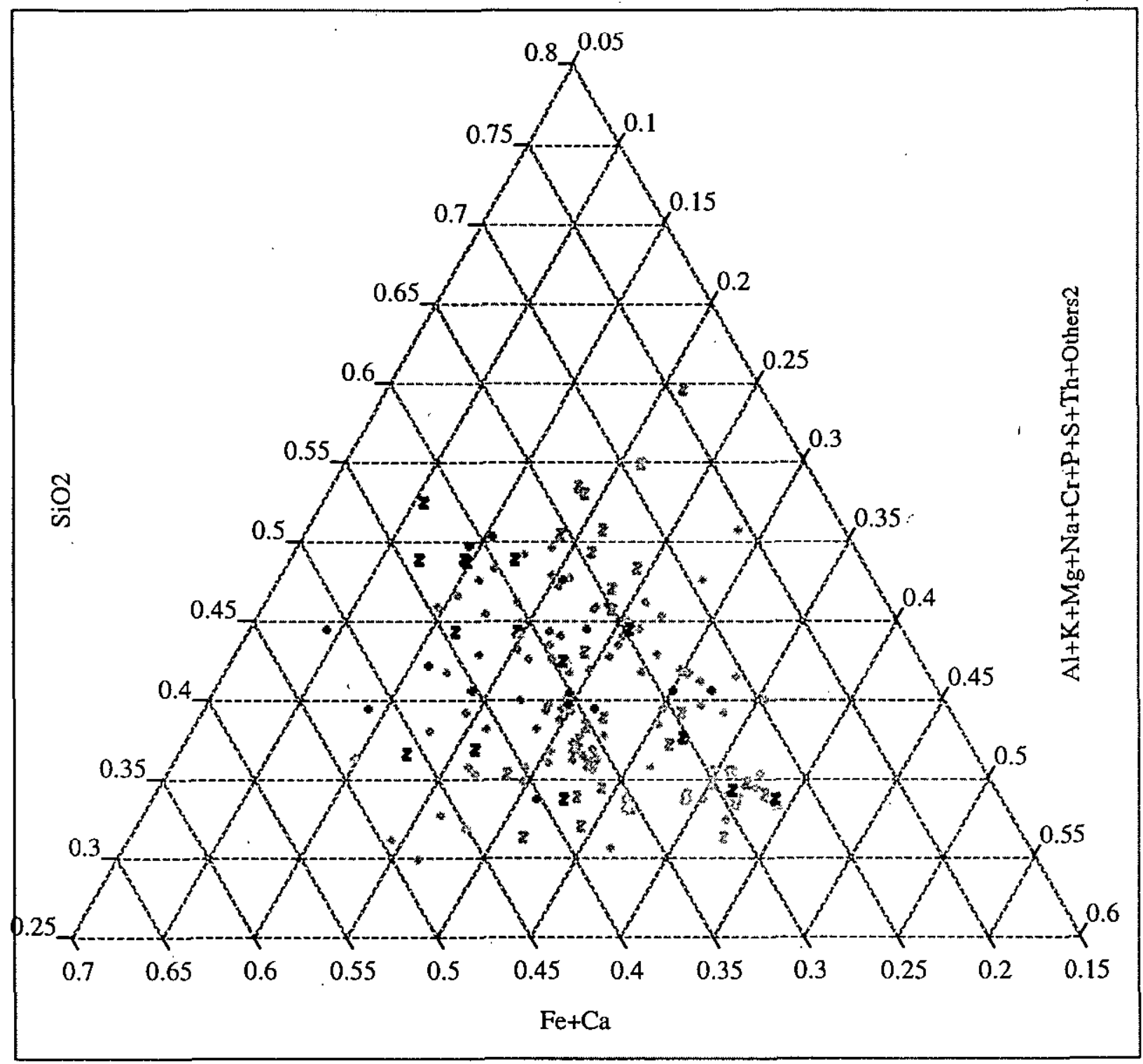

Figure 6 - Ternary Diagram with the Results of Phase VII Testing ( $\mathrm{z}=$ unacceptable glass; $+=$ acceptable glass;

BOLD symbol $=$ Phase VII glass)

\section{Radioactive Confirmation}

In FY97, a radioactive demonstration of the glass formulation was performed with MVST Tank 25 sludge. In FY98, radioactive demonstrations were performed with three separate samples of sludge from the GAAT, OHF and BVEST tank farms. Based upon results of glass testing with simulants, SRTC recommended that the GAAT and BVEST demonstrations be performed at a 45 wt $\%$ sludge oxide loading and the OHF demonstration at $40 \mathrm{wt} \%$ loading. The glass formers consisted of $62 \mathrm{wt} \% \mathrm{SiO}_{2}, 22 \mathrm{wt} \% \mathrm{Fe}_{2} \mathrm{O}_{3}$ and $16 \mathrm{wt} \% \mathrm{CaO}$ for all of the radioactive demonstrations. The PCT results for the simulant work are given in Table 20. ORNL is expected to report on the results of the radioactive demonstrations. 
Table 20 - PCT Results (in $\mathrm{g} / \mathrm{L}$ ) for the Confirmation Studies

\begin{tabular}{|c|c|c|c|}
\hline ID & Ca & Si & Na \\
\hline GAAT & 0.00 & 0.51 & 1.44 \\
\hline BVEST & 0.06 & 0.11 & 0.63 \\
\hline OHF & 0.04 & 0.09 & 0.49 \\
\hline
\end{tabular}

\section{Conclusions}

Using a glass-former composition of $62 \mathrm{wt} \% \mathrm{SiO}_{2}, 22 \mathrm{wt} \% \mathrm{Fe}_{2} \mathrm{O}_{3}$ and $16 \mathrm{wt} \% \mathrm{CaO}$, high waste loadings (45-50 wt\% oxides) of the ORNL sludge can be successfully incorporated into a sodalime-silica glass. These glasses have adequate processing properties (liquidus and viscosity) and are very durable. While not all combinations of sludge compositions produce acceptable glasses, a region on a ternary diagram was found where acceptable glass would be expected. For the majority of the individual tank compositions and for the overall sludge composition, acceptable glasses are produced. Since ORNL intends to combine the GAAT, BVEST and OHF tanks into the MVST tank farm, the composition of the sludge will be similar to the overall blend composition and thus, all of the waste could be immobilized at a waste loading of at least $45 \mathrm{wt} \%$ sludge oxides.

\section{References}

1. M. K. Andrews and J. R. Harbour, Preliminary Cost Comparison of Vitrification and Grouting for Oak Ridge Tank Waste: Costs for Vitrification, WSRC-TR-97-00392, November, 1997.

2. ASTM Procedure, C-1286-94, Determining Chemical Durability of Nuclear Waste Glasses: The Product Consistency Test (PCT).

3. U.S. Department of Energy, Environmental Assessment Waste Form Selection for SRP High-Level Waste, USDOE Report DOE-EA-0179, July, 1982.

4. M. K. Andrews, J. R. Harbour, T. B. Edwards and P. J. Workman, Glass Waste Forms for Oak Ridge Tank Wastes: Fiscal Year 1997 Report for Task Plan SR-16WT-31, Task A (U), WSRC-TR-97-00391, October, 1997.

5. J. M. Keller, J. M. Giaquinto, and A. M. Meeks, Characterization of the MVST Waste Tanks Located at ORNL, ORNL/TM-13357, December, 1996.

6. C. K. Bayne, S. M. DePaoli, J. R. DeVore, D. J. Downing, and J. M. Keller, Statistical Description of Liquid Low-Level Waste System Transuranic Wastes at Oak Ridge National Laboratory, Oak Ridge, Tennessee, ORNL/TM-13351, December, 1996.

7. C. M. Jantzen, N. E. Bibler, D. C. Beam, C. L. Crawford, and M. A. Pickett, Characterization of the Defense Waste Processing Facility (DWPF) Environmental assessment (EA) Glass Standard Reference Material (U), WSRC-TR-92-346, Rev. 1, June, 1993.

\section{Attachments}

Appendix I - Overview of the Statistical Approach

Appendix II - Individual Tank Sludge Compositions 


\section{APPENDIX I:}

\section{OVERVIEW OF THE STATISTICAL APPROACH}

A phased-approach was used to investigate the viability of vitrifying the Oak Ridge tank waste. For the phases driven primarily by a statistical approach, glasses were selected using methods available for designing and analyzing mixture experiments. In this appendix, an overview of these statistical methods is provided.

\section{IDENTIFYING THE FEATURES OF A MIXTURE DESIGN}

Property models that relate process or product characteristics, such as liquidus temperature, to feed composition are inherently difficult due to the large number of constituents in the feed. Designing experiments to explore these relationships must overcome this problem of high dimensionality as well as one other complexity---the glass composition must be considered as a mixture.

The response of a mixture system, consisting of q components, depends only on the proportions of the constituents and not on the total amount of the mixture. This forces each of the design points to satisfy the following mathematical constraints:

$$
0 \leq x_{i} \leq 1 \quad \text { and } \quad \sum_{i=1}^{q} x_{i}=1
$$

where $x_{i}$ is the concentration of oxide $i$ (as a mass or weight fraction) in the mixture consisting of q components [1].

At each phase of this study, there were additional restrictions on the range of each of these oxide concentrations. These restrictions were based upon the current understanding of this problem and were expressed via ranges for each of the oxides of interest.

Thus, the mixtures of interest for this study had to satisfy the following set of constraints

$$
0 \leq x_{i} \leq 1, \quad \sum_{i=1}^{q} x_{i}=1, \quad \text { and } \quad a_{i} \leq x_{i} \leq b_{i}
$$

where $x_{i}$ is the concentration of oxide $i$ (as a weight fraction) in the mixture consisting of $q$ (where $q$ depended on the particular test phase) components and the ranges, $a_{i}$ and $b_{i}$, for each oxide [1].

The region of oxide concentrations that satisfy the constraints of (2) defines the candidate design space and forms a (q-1)-dimensional region. At each phase of the tests, the experimental design that was to be selected for studying the process and product properties for this project would include points chosen from this region.

\section{SELECTING CANDIDATE DESIGN POINTS}

The geometric shape of the region bound by the constraints given by (2) is in general a 
hyperpolyhedron, and because the vertices of this region represent extreme conditions of the operating environment, they are often a good place to start in specifying the design points to be included in the experiment. As might be expected for this (q-1)-dimensional hyperpolyhedron problem, the number of such extreme vertices can be somewhat large. Help is available in the form of published algorithms that can be used to generate these vertices. These algorithms have been incorporated into several commercially available software programs that perform computer-aided design of experiments.

Two such programs were used as part of this study; they are SAS/QC ${ }^{\circledR}$ Software and JMP ${ }^{\circledR}$ both from SAS Institute, Inc.[2,3]. These software packages were used to generate a collection of extreme vertices that bound the region of interest for a particular test phase. For mixture problems, the set of extreme vertices is usually a good place to start in looking for candidate design points. However, there are other compositions, in addition to these extreme vertices, that should be considered for inclusion in this design. It is usually desirable to consider points between the vertices as candidate design points. These points are called centroids. A centroid is the average of points that share a constraint boundary [3]. Centroid points of various degrees can be generated and added as candidate design points. The overall centroid is determined by averaging all of the extreme vertices. The experimental design capabilities of the statistical packages were used to generate all of the extreme vertices and an overall centroid for each of the glass compositional regions of interest. The total number of glasses generated by this approach were usually so large that there was a need to reduce the actual compositions tested to a (small) fraction of these candidate points.

\section{THE MODEL TO BE INVESTIGATED}

The glass properties of primary interest in this study are liquidus temperature and viscosity, also of interest is durability. Liquidus temperature defines a lower limit on melter temperature to avoid forming non-homogeneous glass, which directly affects processability and could potentially affect durability. Durability is important because it directly affects the reliable storage of the glass. Viscosity affects the ability to process the glass, imposing pouring and/or flow constraints.

The effort to reduce the number of candidate compositions revolves around the model that is to be investigated in the study of these properties. The primary model to be examined using the data resulting from the designed experiment being developed here is a linear (first-order) empirical model of the form

$$
y=\beta_{1} x_{1}+\beta_{2} x_{2}+\cdots+\beta_{q} x_{q}+\varepsilon
$$

where $y$ is a response of interest (such as liquidus temperature), $\beta_{\mathrm{i}}$ is the unknown coefficient relating oxide $x_{i}(i=1,2, \ldots, q)$ to $y, \varepsilon$ is an error term which is assumed to have a zero mean and constant variance. 1

\footnotetext{
${ }^{1}$ Even though only subjective measurements were available for the two primary responses, liquidus and viscosity, these values were modeled, at each test phase, in an effort to identify the important components and to identify the composition region with acceptable property behavior.
} 


\section{CRITERIA FOR SELECTING DESIGN}

The computer-aided design of experiments routines, available to help with these mixture problems, utilize one or more of the design optimality criteria that can be used to choose a set of points (the design) from a candidate list of points. Almost all of these computeraided design routines are model dependent. Once a mixture model is chosen, such as the linear model given by (3), and a list of candidate design points is specified, such as the set of all extreme vertices plus centroid, a particular design (of a designated size) is selected from the candidate points that minimizes or maximizes a particular criterion. A final design may be selected from these designs of varying sizes using this same, and/or additional, criteria along with economic considerations.

Some of the more popular criteria that have been proposed for choosing a design are

a. A-optimality, which seeks to minimize the average variance of the estimates of the $\beta_{i}$ 's.

b. D-optimality, which seeks to minimize the determinant of $\left(\mathbf{X}^{\prime} \mathbf{X}\right)^{-1}$ where each row of the matrix $\mathbf{X}$ is a design point, i.e., a composition given by $x_{1}, x_{2}, \ldots, x_{q}$.

c. G-optimality, which seeks to minimize the maximum prediction variance over a specified set of candidate design points.

These are model-dependent criteria, and a design that is optimal for one model form, for example a first-degree model such as (3), will not necessarily be optimal for another model such as a second-degree model [4]. However, since these criteria are varianceminimizing criteria, a design that is optimal for a given model using one of the above criteria is usually near-optimal for the same model with respect to the other criteria [4].

A feature of the JMP software package is its D-Optimal Design routine that uses criteria (b) to choose a set of points (the design) from a candidate list of points [3]. Values of the (a)-(c) criteria, denoted as A-efficiency, D-efficiency, and G-efficiency, respectively, are provided as part of the output from this routine. In addition, the correlations of the estimates of the $\beta_{i}$ 's for the optimal design are provided by this routine.

\section{SOME ADDITIONAL COMMENTS REGARDING THE DESIGNS}

For those phases directed by a statistical approach, a first-order model was used as the driver in selecting the design points. It was assumed that such a linear function of the oxides making up the glass composition would be adequate to model the properties of interest. But even when such a first-order model may be adequate, there is a need to test this assumption. There is a need to ask the questions, "Does the linear model adequately fit the observed response values? Is there an indication of a lack of fit?" For most of these test phases, the overall centroid of the composition region was included as a design point so that it might be used as a check point for the fitted model. If there were nonlinear bending in the response of liquidus temperature or viscosity over the hyperpolyhedron defined by (2), there should be some indication via a lack of fit for the response corresponding to this check point. Thus, it is important that centroids and other interior points be included in the design to serve as indicators for a lack of fit for the linear model, and this was the approach used in this study. 
REFERENCES

[1] Cornell, J. A., Experiments With Mixtures: Designs, Models, and the Analysis of Mixture Data, Second Edition, John Wiley \& Sons, Inc., New York, 1990.

[2] SAS Institute, Inc., SAS/QC Software: Reference, Version 6, First Edition, SAS Institute, Inc., Cary, NC, 1990.

[3] SAS Institute, Inc., JMP Statistics and Graphics Guide, Version 3, SAS Institute, Inc., Cary, NC, 1994.

[4] Snee, R. D., "Experimental Designs for Quadratic Models in Constrained Mixture Spaces," Technometrics, Volume 17, Number 2, May, 1975. 
E. W. Holtzscheiter

\section{Appendix II}

Individual Tank Sludge Compositions 
OHF

GAAT

\begin{tabular}{|c|c|c|c|c|c|c|c|c|c|c|}
\hline & $\mathrm{Tl}$ & T2 & T3 & $T 4$ & T9 & W5 & W6 & W7 & W8 & W9 \\
\hline Element & Elem. Wt\% & Elem. $w+\%$ & Elem. $\mathrm{w}+\%$ & Elem. Wt\% & Elem. Wt\% & Elem. Wt\% & Elem. Wt\% & Elem. Wt\% & Elem. Wt\% & Elem. W+\% \\
\hline $\mathrm{Al}$ & 2.6200 & 1.5900 & 1.5600 & 0.9320 & 3.4500 & 1.5767 & 1.0877 & 0.5086 & 0.9945 & 0.8847 \\
\hline $\mathrm{Ba}$ & 0.0000 & 0.0000 & 0.0000 & 0.0000 & 0.0000 & 0.0000 & 0.0184 & 0.0000 & 0.0000 & 0.0000 \\
\hline $\mathrm{Ca}$ & 2.7900 & 3.6600 & 3.7900 & 2.0600 & 3.2800 & 1.3400 & 2.9700 & 0.1329 & 0.8340 & 0.6115 \\
\hline $\mathrm{Cr}$ & 0.0079 & 0.0241 & 0.0052 & 0.0118 & 0.0085 & 0.1273 & 0.1370 & 0.0198 & 0.0272 & 0.0120 \\
\hline $\mathrm{Cu}$ & 0.0156 & 0.0126 & 0.0000 & 0.0293 & 0.0117 & 0.0000 & 0.0000 & 0.0000 & 0.0000 & 0.0000 \\
\hline $\mathrm{Fe}$ & 0.3440 & 0.6240 & 0.7790 & 0.3150 & 1.7900 & 1.7667 & 1.3387 & 0.3952 & 0.7125 & 0.3257 \\
\hline$K$ & 0.1680 & 0.2130 & 0.6140 & 0.2080 & 0.0974 & 0.0418 & 0.0768 & 0.9671 & 0.1427 & 0.3242 \\
\hline $\mathrm{Mg}$ & 0.3460 & 0.3170 & 0.3570 & 0.1730 & 0.5140 & 0.3620 & 0.1735 & 0.0279 & 0.6900 & 0.0728 \\
\hline $\mathrm{Mn}$ & 0.0318 & 0.0336 & 0.0199 & 0.0472 & 0.0337 & 0.0413 & 0.1040 & 0.0073 & 0.0141 & 0.0145 \\
\hline $\mathrm{Na}$ & 0.4040 & 0.5060 & 1.8800 & 0.7400 & 0.6640 & 3.4900 & 4.1550 & 4.8025 & 0.7492 & 0.6517 \\
\hline $\mathrm{P}$ & 0.6940 & 0.8340 & 0.7510 & 0.8080 & 1.2600 & 0.1024 & 0.2065 & 0.1514 & 0.0090 & 0.0965 \\
\hline $\mathrm{Pb}$ & 0.0568 & 0.0654 & 0.0229 & 0.0598 & 0.0529 & 0.0283 & 0.3840 & 0.0040 & 0.1370 & 0.0500 \\
\hline $\mathrm{Sb}$ & 0.0000 & 0.0000 & 0.0000 & 0.0000 & 0.0000 & 0.0000 & 0.0000 & 0.0000 & 0.0000 & 0.0000 \\
\hline $\mathrm{Si}$ & 0.4010 & 0.3950 & 3.2500 & 0.4570 & 0.3640 & 0.0000 & 0.3360 & 0.0000 & 0.0000 & 0.0000 \\
\hline $\mathrm{Sr}$ & 0.0946 & 0.0992 & 0.0282 & 0.0334 & 0.0908 & 0.0030 & 0.0061 & 0.0010 & 0.0047 & 0.0039 \\
\hline Th & 9.0500 & 9.4300 & 7.7500 & 12.4000 & 5.6800 & 0.2928 & 0.1122 & 0.4114 & 1.4212 & 0.6042 \\
\hline $\mathrm{U}$ & 0.2420 & 0.2090 & 0.5920 & 0.7870 & 0.2510 & 1.5774 & 3.1680 & 9.7223 & 0.5444 & 2.2275 \\
\hline$F$ & 0.0176 & 0.0233 & 0.0257 & 0.0272 & 0.0140 & 0.1973 & 0.7432 & 0.1720 & 0.0329 & 0.0192 \\
\hline $\mathrm{Cl}$ & 0.0247 & 0.0366 & 0.0947 & 0.0401 & 0.3760 & 0.0073 & 0.0155 & 0.2737 & 0.0329 & 0.0137 \\
\hline SO4 & 0.0339 & 0.0726 & 0.2960 & 0.1210 & 0.0616 & 0.0291 & 0.7867 & 0.7720 & 0.3683 & 0.0536 \\
\hline $\mathrm{Zn}$ & 0.0178 & 0.0236 & 0.0151 & 0.0183 & 0.0149 & 0.0029 & 0.0174 & 0.0033 & 0.0091 & 0.0056 \\
\hline
\end{tabular}




\begin{tabular}{|c|c|c|c|c|c|c|c|c|c|c|}
\hline & GAAT & BVEST & & & MVST & & & & & \\
\hline & W10 & W21 & W22 & W23 & W-24 & W25 & $W-26$ & $W-27$ & W-28 & $\overline{W-31}$ \\
\hline Element & Elem. Wt\% & Elem. Wt\% & Elem. $W+\%$ & Elem. $W+\%$ & Elem. $\mathrm{Wt} \%$ & Elem. Wt\% & Elem. Wt\% & Elem. Wł\% & Elem. Wł\% & Elem. Wt\% \\
\hline $\mathrm{Al}$ & 3.0850 & 0.1230 & 0.2100 & 0.1740 & 0.3330 & 0.5810 & 0.1980 & 0.2250 & 0.0571 & 1.2700 \\
\hline $\mathrm{Ba}$ & 0.0136 & 0.0000 & 0.0000 & 0.0000 & 0.0000 & 0.0000 & 0.0000 & 0.0000 & 0.0000 & 0.0000 \\
\hline $\mathrm{Ca}$ & 0.8657 & 6.8300 & 4.3500 & 6.3200 & 5.1200 & 5.0800 & 4.5900 & 4.3700 & 4.5800 & 2.4100 \\
\hline $\mathrm{Cr}$ & 0.0169 & 0.0229 & 0.0132 & 0.0194 & 0.0061 & 0.0092 & 0.0074 & 0.0055 & 0.0055 & 0.0130 \\
\hline $\mathrm{Cu}$ & 0.0000 & 0.0000 & 0.0000 & 0.0000 & 0.0000 & 0.0000 & 0.0000 & 0.0000 & 0.0000 & 0.0000 \\
\hline $\mathrm{Fe}$ & 0.7927 & 0.2980 & 0.3090 & 0.2020 & 0.1250 & 0.1810 & 0.1011 & 0.0935 & 0.0599 & 0.2820 \\
\hline $\mathrm{K}$ & 0.3402 & 1.1500 & 0.3260 & 2.0500 & 1.3400 & 0.8850 & 2.5300 & 0.6970 & 1.4600 & 0.8320 \\
\hline $\mathrm{Mg}$ & 0.1023 & 1.1500 & 0.5110 & 1.4500 & 0.9280 & 0.7650 & 1.4700 & 0.7820 & 1.4500 & 0.2170 \\
\hline $\mathrm{Mn}$ & 0.0188 & 0.0173 & 0.0784 & 0.0937 & 0.0084 & 0.0140 & 0.0102 & 0.0065 & 0.0091 & 0.0247 \\
\hline $\mathrm{Na}$ & 1.3450 & 4.4000 & 1.0000 & 7.5500 & 4.8800 & 5.2100 & 4.8900 & 5.8200 & 6.1000 & 6.0600 \\
\hline $\mathrm{P}$ & 0.0087 & 0.3550 & 1.0400 & 0.3570 & 0.1240 & 0.1850 & 0.1070 & 0.1000 & 0.0907 & 0.4240 \\
\hline $\mathrm{Pb}$ & 0.0699 & 0.0394 & 0.0427 & 0.1200 & 0.0303 & 0.0442 & 0.0212 & 0.0157 & 0.0195 & 0.0764 \\
\hline $\mathrm{Sb}$ & 0.0000 & 0.0000 & 0.0000 & 0.0000 & 0.0000 & 0.0114 & 0.0000 & 0.0000 & 0.0000 & 0.0000 \\
\hline Si & 0.0000 & 0.3900 & 0.5290 & 0.3500 & 0.3820 & 0.8890 & 0.2100 & 0.3860 & 0.1080 & 1.0200 \\
\hline $\mathrm{Sr}$ & 0.0054 & 0.0266 & 0.0175 & 0.0473 & 0.0283 & 0.0325 & 0.0254 & 0.0107 & 0.0151 & 0.0174 \\
\hline Th & 0.6770 & 0.8650 & 0.9580 & 2.9600 & 0.3270 & 0.9250 & 0.3280 & 0.1290 & 0.1360 & 2.0700 \\
\hline U & 1.3987 & 2.6300 & 3.5600 & 0.7990 & 0.6780 & 0.7660 & 1.9400 & 1.1700 & 1.8500 & 1.9800 \\
\hline $\mathrm{F}$ & 0.0392 & 0.0023 & 0.0021 & 0.0149 & 0.0103 & 0.0118 & 0.0000 & 0.0000 & 0.0000 & 0.0125 \\
\hline $\mathrm{Cl}$ & 0.0565 & 0.1370 & 0.0249 & 0.3420 & 0.2770 & 0.2110 & 0.3070 & 0.2280 & 0.3460 & 0.2570 \\
\hline $\mathrm{SO} 4$ & 0.2197 & 0.6030 & $\overline{0.0191}$ & 0.3850 & 0.1370 & 0.1750 & 0.2120 & 0.0549 & 0.1773 & 0.1090 \\
\hline $\mathrm{Zn}$ & 0.0111 & 0.0810 & 0.1060 & 0.0588 & 0.0479 & 0.0285 & 0.0405 & 0.0360 & 0.0278 & 0.0125 \\
\hline
\end{tabular}




\section{Distribution}

M. K. Andrews, 773-A

N. E. Bibler, 773-A

D. A. Crowley, 773-43A

T. B. Edwards, 773-42A

C. R. Goetzman, 773-A

T. S. Gutmann, 704-S

J. R. Harbour, 773-43A

E. W. Holtzscheiter, 773-A

L. F. Landon, 704-1T

J. P. Morin, 703-H

L. M. Papouchado, 773-A

C. T. Randall, 704-T

R. C. Tuckfield, 773-42A

P. J. Workman, 773-A

STI (4 copies), 703-43A

G. C. Notch (8 copies)

PNNL

P. O. Box 999, MSIN K9-69.

Richland, WA 99352

J. A. Frey

U.S. DOE - Richland Operations Office

P. O. Box 550, MS K8-50

Richland, WA 99352

T. B. Conley

T. E. Kent

C. P. McGinnis

S. M. Robinson

R. D. Spence

ORNL

P.O. Box 2008

Oak Ridge, TN 37831

C. M. Mims

J. R. Noble-Dial

U.S. DOE - Oak Ridge Operations Office

P.O. Box 2001

Oak Ridge, TN 37830 